\title{
A Sixth Dynasty Stela from Abydos
}

\section{Dr. Ahmed Hamdy Abdelmoniem}

Lecturer of Egyptology, Faculty of Arts,

Alexandria University 


\section{Abstract:}

The limestone stela described in the following pages is currently located in the Cairo Museum under the number CG 1579 and SR 2/15196, it belongs to an official named Ni-Pepy.

The stela most probably was from his tomb which was likely located in the middle necropolis of Abydos ${ }^{(1)}$, although the stela was mentioned by Mariette ${ }^{(2)}$, Sethe ${ }^{(3)}$ and Borchardt ${ }^{(4)}$, it was never published fully before.

\section{Description:}

It is a rectangular limestone stela measuring 130 c.m high, 67 c.m in width and 14 c.m in thickness, it is in a good state of preservation with a slight fraction in its lower right side, no remains of colours can be recognized. All the texts and the figure of the owner of the stela Ni-Pepy are all well incised ${ }^{(5)}$.

The stela is divided into three parts, the upper one is dominated by five lines of inscriptions where the signs are oriented from right to left, the lower-framing line of these five lines of inscriptions delineates the upper part of the stela from the lower two parts.

As for the lower two parts, they consist of a left part, which is much larger than the right one, where it shows the stela's owner standing in the addressing posture ${ }^{(6)}$, where he is acting in the pose of speech $^{(7)}$, He appears barefooted wearing a short knee length kilt ${ }^{(8)}$ tight at the waist with a triangular front projection, his left leg is extended forward, he is wearing a broad collar in his neck and two bands in his wrists. The face of the deceased is destroyed with some exceptions can hardly observed as the nose, the earlobe and the lips ${ }^{(9)}$, his head is covered with a shoulder length wig leaving the ear uncovered $^{(10)}$, whilst the right part of that lower section of the stela displays only two vertical columns of inscriptions, in which the signs are directed from right to left, these two vertical lines include in each two titles for Ni-Pepy. 


\section{Text and Translation:}

(a) The horizontal five inscriptions:

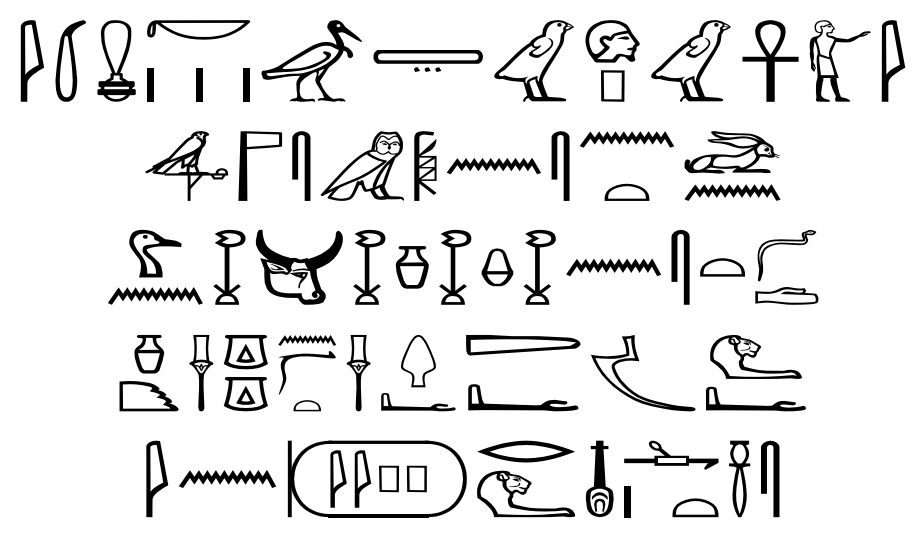

I C nhw tpw t3 b3kw miti..$^{(11)}$

Wnnt.sn (m) šms ntitr

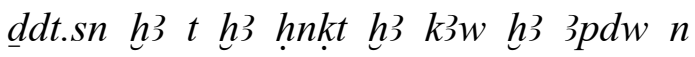

h3ty-r m3e im3-r hrp nsty hrp h3ts $\mathrm{km}$

smr-w'ty iry nfr-h3t Ni-Ppy

\section{Translation:}

(1)O, the living ones upon the earth, (men) servants like me (2) shall they be (in) the accompany of the god (3) Shall they say (utter) a thousand loaves of bread, a thousand jars of beer, a thousand of bull, a thousand of fowl to (4) "True count", "gracious of arm", "director of the two thrones", "controller of the black jar"(12), (5) "Sole companion", "keeper of the headdress"(13), Ni-

Pepy. 


\section{(b) The vertical two Inscriptions:}

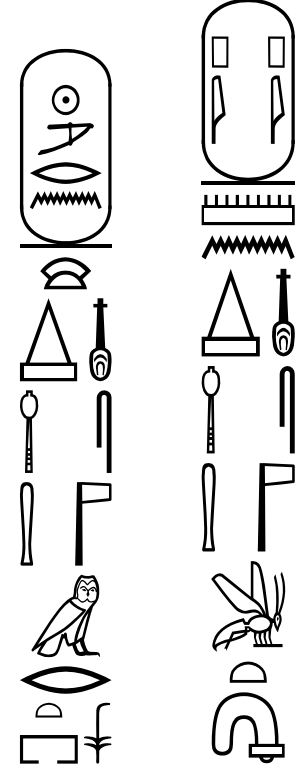

shd $h m(w)-n \underline{t r}$ Mn-nfr-Ppy htmty-bity sḥ $h m(w)-n t r \quad H^{\top}-n f r-M r-n-$ $R^{\odot}$ imy-r pr-nswt

\section{Translation:}

(1) "Inspector of $h m-n \underline{t} r$ priests of the pyramid of Pepi I", "sealer of the king of Lower Egypt" (14), (2) "Inspector of hm-ntr priests of the pyramid (the perfection - of - Merenre - appears - in Glory)", "overseer of the king's domain" (15).

\section{The Commentary:}

\section{(A)The Name and Titles of Ni-Ppy:}

The name Ni-Ppy was known since the Old Kingdom ${ }^{(16)}$, Ranke translated it by "the one who belongs to (king) Pepi",(17), Kuraszkiewicz noted that there were three individuals bore the name of Ni-Ppy in the Old Kingdom, two of them came from the Memphite necropolis nearby Pepy II's pyramid ${ }^{(18)}$ while the last one was buried in Abydos ${ }^{(19)}$, By the end of the Old Kingdom the private names which were incorporated with the names of the kings were very common ${ }^{(20)}$. 


\section{The stela presents ten titles held by Ni-Pepy during his long career, which are arranged in alphabetical order as follows:}

(1) im3-c (gracious of arm) $)^{(21)}$.

(2) 'Imy-r pr-nswt (overseer of the king's domain) ${ }^{(22)}$.

(3) 'Iry $n f r-h 3 t$ (keeper of the headdress) ${ }^{(23)}$.

(4) h3ty-e mic (true count) ${ }^{(24)}$.

(5) hrp nsty (director of the two thrones) ${ }^{(25)}$.

(6) hrp h3ts $\mathrm{km}$ (director of the black jar) ${ }^{(26)}$.

(7) htmty-bity ${ }^{(27)}$ (sealer of the king of lower Egypt) ${ }^{(28)}$.

(8) Smr-wety (sole companion) ${ }^{(29)}$.

(9) $s h \underline{d} \quad h m(w)-n \underline{t} r \quad M n-n f r-P p y$ (inspector of $h m-n \underline{t} r$ priests of the pyramid of Pepi I) ${ }^{(30)}$.

(10) $s \underline{h} \underline{d} h m(w)-n \underline{t r} \quad H^{\top}-n f r-M r-n-R^{e}$ (inspector of $h m-n \underline{t r}$ priests of the pyramid of Merenre) ${ }^{(31)}$.

(1) im3-r: Wörterbuch read the title as im3- ${ }^{(32)}$, Gunn and Helck translated it as : "agreeable hand"(33), while Jones translated it as "gracious of arm", (34).

It was known since the reign of king "Den"(35), by the time of the second dynasty it was linked with the court ${ }^{(36)}$, it continued in use thereafter where it sometimes appeared during the fourth and early fifth dynasties ${ }^{(37)}$, but by the second half of the fifth dynasty and during the sixth dynasty it became of high consideration ${ }^{(38)}$.

Altenmüller noted that it was a regular court office ${ }^{(39)}$, Strudwick presented a table of twenty im 3- ${ }^{-}$who carried the title during the Old Kingdom, seventeen of them came from the Memphite necropolis, while three were buried in the provinces ${ }^{(40)}$.

For the meaning of that title and so determine the functions of its holder, it is noticed that it consists of two components, the ideogram 乌 (41) which is read as $i m$ 3 or $i 3 m^{(42)}$ and translated as "kind" or "gracious" or sometimes as "favorite"(43), while the other component is the unilateral sign 0 "which means hand or arm ${ }^{(44)}$ or "assistant" when it was involved in titles ${ }^{(45)}$. 
It is worth commenting that the $i m 3 / 33 m$ tree was mentioned in the Pyramid Texts where it attends, serves and supplies the dead king with all his provisions in the afterlife ${ }^{(46)}$ and later the Coffin Texts confirmed the same role for that tree ${ }^{(47)}$.

Consequently, It was a divine tree which guaranteed protection and supplies for the king in the afterlife, and since the king's afterlife is a reflection of his earthly ideas and life, so it would be acceptable that im3- - was a person who offered protection and provisions for the living king, as he performed the role of $i m 3$ tree but in the real life.

Thus the im3-` was a court title - as Altenmüller mentioned before but of high status that was confirmed by the fact that twelve of the twenty holders of the title were vezirs ${ }^{(48)}$ and the title's holder, Ni-Ppy in our case, was responsible for serving and attending to the living king.

(2) imy-r pr-nswt: the holder of that title was in charge of managing and administrating the royal palace ${ }^{(49)}$, the title was found in the titularies of many officials in the Memphite necropolis as the vizier Hnty-k3i / ihh hi $i^{(50)}$ and in the provinces as Ni-Ppy of Abydos ${ }^{(51)}$ and ' $I m$ htp of Sheikh-Said ${ }^{(52)}$.

(3) Iry $n f r-h 3 t$ : is a court title indicates an office related to the king's headdress ${ }^{(53)}$, Wörterbuch mentioned that the word $n f r-h 3 t$ means diadem ${ }^{(54)}$, thus it was a headdress other than a wig ${ }^{(55)}$, it might be a knotted head band or headdress, this meaning is proved by a New

Kingdom text where the verb $t s$ was followed by the determinative

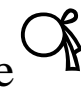
(56) which indicates a headdress.

The role of the holders of 'Iry $n f r-h 3 t$ is to be a keeper of the royal headdresses including wigs, their keeping, storage as well as the responsibilities of adorning the head of the sovereign as reflected from title iry $n f r-h 3 t m$ sh $k r r r^{(57)}$.

Although the title was a court title, it was attested also in the provinces as: Ni-Ppy - the stela's owner -, k3i-hb / Tti of Akhmim ${ }^{(58)}, P p y-{ }^{\complement} n h-$ $h r y-i b$ of Meir ${ }^{(59)}$ and $I^{\prime} p$ of elsaff ${ }^{(60)}$.

(4) h3ty-r $m 3^{r}$ : It was known since the time of Unis till the end of the Old Kingdom ${ }^{(61)}$, Different opinions were raised concerning the 
addition of $m 3^{r}$ as an adjective subsequent to titles, Wörterbuch and Edgerton mentioned that it shows that the job was actually practised ${ }^{(62)}$, Kanawati suggested that it might reveal a degree of superiority or significance for the title's holder ${ }^{(63)}$, whilst Gunn, James and Fischer believed that such addition didnot reflect any significance or status for the holder of the title ${ }^{(64)}$, this office was the higher rank held by Ni-Ppy in his long career track.

(5) hrp nsty: This court title is composed of two words: hrp which means "director" (65) and nsty which means the "two thrones"(66). Gardiner believed that the two thrones referred to the two seats in which the king and queen sat on during taking their meals with each other in the palace ${ }^{(67)}$.

Although the title was held by viziers in the middle of the fifth dynasty ${ }^{(68)}$, Both Gardiner and Helck supposed that it was a middle rank performed by the servants of the royal palace ${ }^{(69)}$, it may be one of the primary offices carried out by Ni-Ppy in his early career path

(6) hrp h3ts $\mathrm{km}$ : The title was known since the late of the fourth dynasty ${ }^{(70)}$ and continued in use till the end of the Old Kingdom in the Memphite Capital and in the provinces as well ${ }^{(71)}$.

The word $h 3 t s \mathrm{~km}$ which means the black jar was likely referred to the jar of wine ${ }^{(72)}$, It is worth commenting that the title hrp h3ts $\mathrm{km}$ and the previous title hrp nsty were always frequently found together with each other ${ }^{(73)}$, which led Gardiner to note that both titles were connected with the royal table ${ }^{(74)}$, thus the hrp $h 3 t s \mathrm{~km} s$ were most probably in charge of pouring wine to the royal couple during taking their meals.

(7) htmty-bity: It was first known since the archaic period ${ }^{(75)}$ and continued in use till the end of the Old Kingdom ${ }^{(76)}$.

The title was widely spread in the Old Kingdom in both the Memphite necropolis and the provinces as well ${ }^{(77)}$, this is due to the urgent need for the king and the state to store different kinds of raw materials and food in all the provinces.

These different kinds of raw materials and food were stored and secured in large stores with the supervision of the local chief ${ }^{(78)}$, such 
great responsibility on local chiefs made the office and services of htmty-bity always required ${ }^{(79)}$.

Consequently, as h3ty- ${ }^{-} m 3^{`}$ and htmty-bity, Ni-Ppy was in charge of all the stores of raw materials and food in the eighth nome of Upper Egypt (Abydos).

(8) $s m r$ - $w^{\text {'ty: }}$ : It was known since the fourth dynasty particularly since the time of Cheops as it was held by $H m-I w n w^{(80)}$ and continued in use till the end of the Old Kingdom in the Memphite capital as well as the provinces ${ }^{(81)}$.

The title smr-w'ty was much debated amongst scholars, some suggest that it was a honorific title that only reflected the standing of its holder and his relationship with the sovereign ${ }^{(82)}$, Fischer noted that it was the lowest of the titles of rank ${ }^{(83)}$ without referring to a particular task that a smr-w'ty could execute, while the royal decrees revealed that smr$w^{\text {'ty }} s$ might have carried out the responsibilities of the royal envoys ${ }^{(84)}$. Consequently, it was a real office with specific tasks performed to the sovereign, it also shows the position gained by $\mathrm{Ni}$ Ppy from his sovereign.

\section{(9) $S \underline{h} \underline{d} h m(w)-n \underline{t} r \quad M n-n f r-P p y$}

\section{(10) $S \underline{h} \underline{d} h m(w)-n \underline{t} r H^{c}-n f r-M r-n-R^{c}$}

$h m(w)$-ntr were one of the temple Phyles which involved beside them other staff and personnel as $w^{c} b(w), \underline{h r} r(w)-h b t$ priests, $h n t y(w)-\check{s}$ and $\underline{d} t$ servants ${ }^{(85)}$, each of them carried out specific tasks in the temple.

Both $h m(w)-n t r$ and $w^{c} b(w)$ priests were responsible for the recitation of the daily rituals and the monthly activities ${ }^{(86)}$, As for Ni-Ppy who was $s \underline{h} \underline{d} h m(w)$-ntr he presided all these temple Phyles in both cult temples of Pepy I and Merenre ${ }^{(87)}$.

According to Muhs these several temple staff and personnel served only for a month in ten, this enabled them to be assigned in more than one mortuary temple ${ }^{(88)}$, as in case of Ni-Ppy who performed the task of this office in both mortuary temples of Pepy I and Merenre I, It is worth to note that such office $s \underline{h} \underline{d} \underline{h} m(w)-n \underline{t} r$ was not linked with gods' temples before the Middle Kingdom ${ }^{(89)}$. 


\section{(B) Dating Criteria:}

The stela shows some artistic and epigraphical features which help to assign and determine a particular date for it:

\section{As for the Artistic Features of dating:}

(1) The stela presents many artistic features which represent the second Old Kingdom style, this style which began since the time of Pepy I till the end of the Eighth dynasty ${ }^{(90)}$ as: the shoulder length wig that leaves the ear uncovered, the broad collar which was worn by the deceased around his neck, the positioning of the earlobe of the deceased on the same line with the bottom of the nose and the depicting of the ears of the deceased precisely vertical without any bending ${ }^{(91)}$.

(2) The deceased is depicting in the addressing posture, which is known by the early of the fifth dynasty, but it became familiar during the sixth dynasty ${ }^{(92)}$.

\section{As for the epigraphical and textual features of dating:}

(3) The stela shows some epigraphical and textual features which characterized the end of the Old Kingdom as: the appearance of the suffix (.sn), in the second and third horizontal inscriptions, without the plural signs $(\mathbf{I} \mathbf{I}$ ) is a frequent feature until the twelfth dynasty ${ }^{(93)}$.

(4) The appearance of the title shd $\underline{h} m(w)-n \underline{t} r+$ royal pyramid complex, is not frequent after the middle of the sixth dynasty in the provinces ${ }^{(94)}$.

(5) The stela displays the formula of "addressing to the living", in the first horizontal line of the stela's inscriptions, in which the deceased asked the passer - by to recite the food prayers ${ }^{(95)}$, which appeared in the third line of the stela, the formula in that situation began from the last years of Pepy I's reign, flourished by the time of Merenre I and continued in that status during the reign of Pepy II and thereafter ${ }^{(96)}$.

(6) The name Ni-Ppy appeared twice only in the Old Kingdom beside the owner of the current stela, both of them were buried nearby Pepy II's pyramid in the Memphite necropolis ${ }^{(97)}$. 


\section{Conclusion:}

(1) The titles held by Ni-Ppy reflected that he began his long career track in the Memphite residence, where he served in the royal palace as reflected from titles (1), (2), (3), (5), (6) and (8), at the same time he served as an inspector of the hm-ntr priests in the mortuary temples of both kings Pepy I and Merenre I, then after a long time in serving the king, Ni-Ppy was appointed as a true count for Abydos as reflected from title (4) and as a part of his responsibility in Abydos to guarantee the security of the stores in the eighth nome he held the title htmty-bity (7).

(2) Ni-Ppy was very trusted by the king that allowed the latter to select him from a high court official to be appointed as the count of Abydos which was the center of the royal administration in Upper Egypt throughout the Old Kingdom.

(3) The titles (1) and (3) show the direct and intimate relationship between Ni-Ppy and the sovereign.

(4) Most probably Ni-Ppy was "overseer of the king's domain" before he was appointed as count of Abydos where the stela was discovered.

(5) Baer suggested a very wide date for Ni-Ppy which started from the reign of Merenre I to the end of the Eighth dynasty ${ }^{(98)}$, but according to the previous mentioned dating criteria, it is clear that the stela is a sixth dynasty stela, but as reflected from (B1) the stela might be dated by the time of Pepy I to the end of the Eighth dynasty, but as (B6) shows that the name Ni-Ppy appeared twice in the Memphite necropolis both came from nearby the pyramid of Pepy II, also (B5) indicates that the formula was introduced since the late years of Pepy I, flourished by the time of Merenre I and continued in the reign of Pepy II, in addition to (B4), so the stela is not earlier than the last years of Pepy I and not later than the middle of the sixth dynasty, if one adds in consideration the two

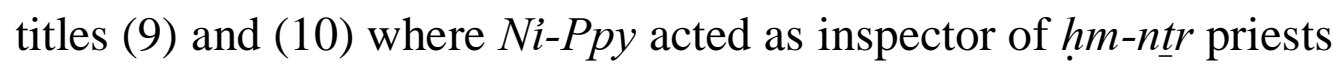
in the mortuary temples of Pepy I and Merenre I so L suggest the 
dating of the stela by the reign of Merenre I to the early years of Pepy II and that Ni-Ppy might be contemporary to the sovereigns Pepy I, Merenre I and the early years (First quarter) of Pepy II. 


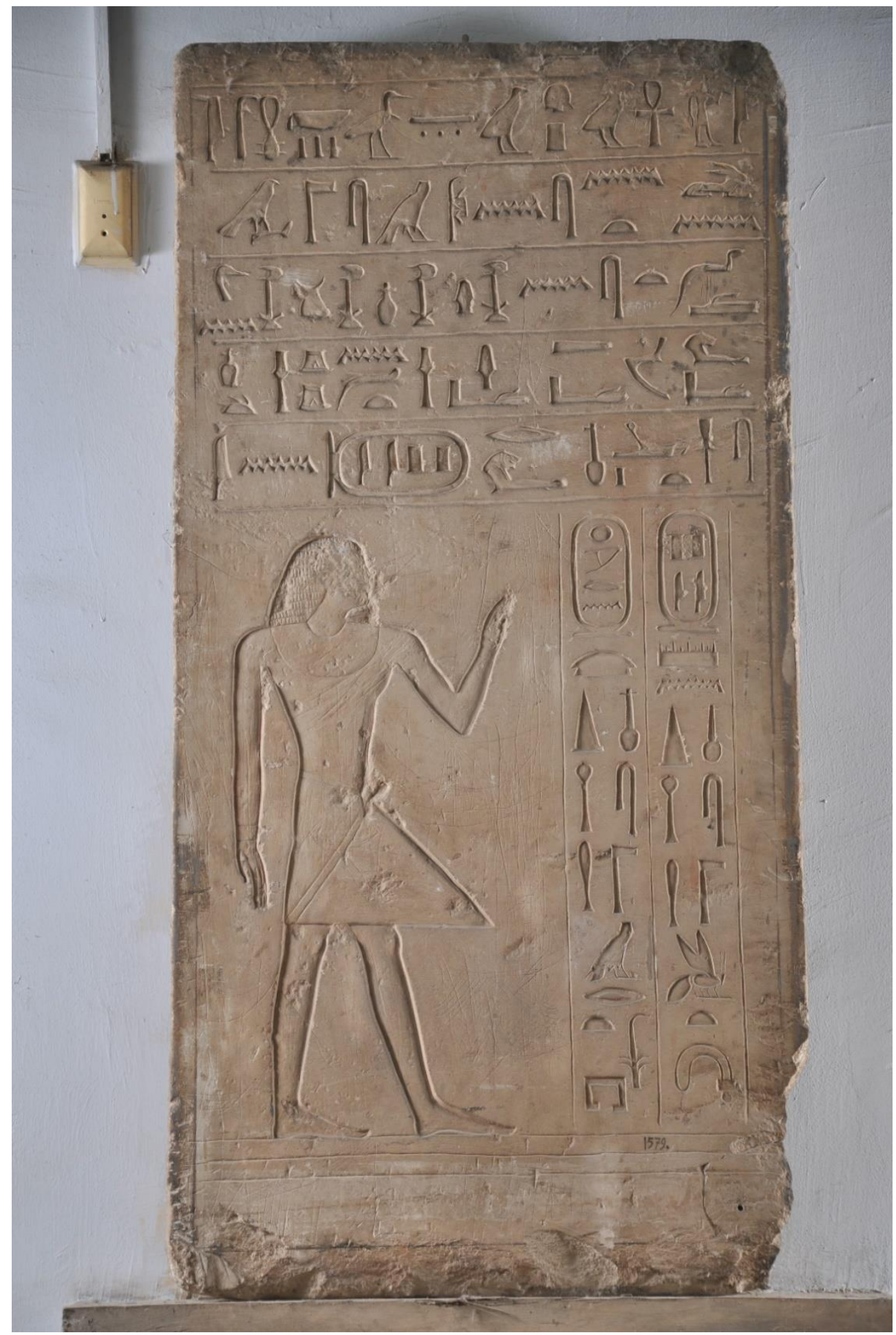




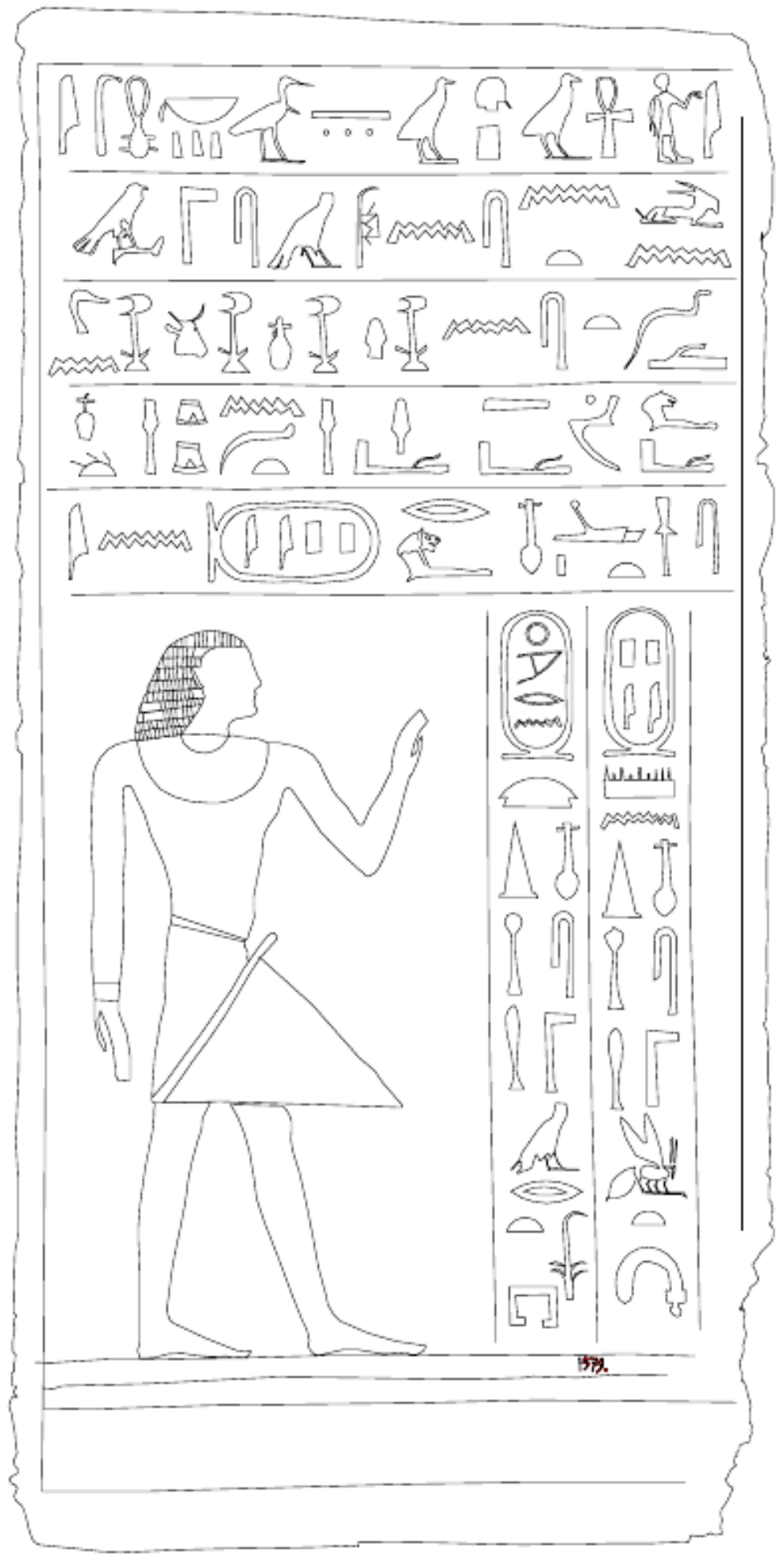


(1) Mariette, A., Catalogue Général des Monuments D’Abydos, p. 89 no. 528.

$\left({ }^{2}\right)$ Mariette, A., Abydos II, pl. 43 b.

$\left({ }^{3}\right)$ Urk I, p. 112.

$\left({ }^{4}\right)$ Borchardt, L., Denkmäler des Alten Reiches II, p. 60.

$\left({ }^{5}\right)$ The sunk relief began to be used for decorating private stelae by the time of Neuserre at least and gradually became the predominant form by the end of the fifth dynasty, El-Khadragy, M., "Two Old Kingdom False doors from Saqqara", p. 43.

$\left({ }^{6}\right)$ Brunner-Traut, E., "Gesten", p. 579 (3a); Fischer, H., The Orientation of Hieroglyphs, p. 49.

( 7 ) The arm is not extended at shoulder height where the elbow brought it down that made the hand reached the shoulder level or slightly higher, BrunnerTraut, E., "Gesten", p. 579 (3a).

$\left.{ }^{8}\right)$ Staehelin, E., Untersuchungen zur agyptischen Tracht im Alten Reich, pl. XXI, fig. 10.

(9) The designing of the stela made by Mariette shows these details, Mariette, A., Abydos II, pl. $43 \mathrm{~b}$, beside the observations made by the Author.

$\left({ }^{10}\right)$ Green, L., "Hairstyles", p. 74.

$\left({ }^{11}\right) \mathrm{Wb}$ II, p.39 [4].

$\left({ }^{12}\right)$ For the translation of titles mentioned in the third horizontal line of inscriptions cf., Jones, D., An Index of Ancient Egyptian Titles I, p. 10: 39; II, pp. 497:1862, 724:2637, 725-726:2642.

$\left({ }^{13}\right)$ For the translation of titles mentioned in the fourth line of the horizontal inscriptions cf., Jones, D., An Index of Ancient Egyptian Titles I, p. 321:1183; II, p. 892:3268.

$\left({ }^{14}\right)$ For the translation of titles attested in the first vertical line of the lower section cf., Jones, D., An Index of Ancient Egyptian titles II, pp. 763, 935: 2775, 3448.

$\left({ }^{15}\right)$ For the translation of titles mentioned in the second vertical column of inscriptions cf., Jones, D., An Index of Ancient Egyptian Titles I, p. 120:482; II, p. 941:3471.

$\left({ }^{16}\right)$ PM III ${ }^{2} / 2$, pp. 427, 686.

$\left({ }^{17}\right)$ Ranke, H., Personennamen I, p. 172:13.

$\left({ }^{18}\right)$ PM III ${ }^{2} / 2$, pp. 427, 686.

$\left({ }^{19}\right)$ Kuraszkiewicz, K., "Two Fragments of False-door frame of Ny-Pepy from west Saqqara", p. 128 n.2, no doubt that the name Ni-Ppy of Abydos mentioned by Kuraszkiewicz was the owner of our current stela.

$\left(^{20}\right)$ For example for that names cf., Ppy-snb and Ppy- ${ }^{-} n h$, Ranke, H., Personennamen I, p. 131:17, 19, Mry-r $r^{c} s n b$, and Mry-r ${ }^{\complement}-d d i$, Ranke, H., Personennamen I, p. 161:3-4, Tti-išt.f and Tti- ${ }^{-} n h(w)$, Ranke, H., Personennamen I, p. 384:12,16.

$\left({ }^{21}\right)$ Jones, D., An Index of Ancient Egyptian Titles I, p. 10:39. 
$\left({ }^{22}\right)$ Jones, D., An Index of Ancient Egyptian Titles I, p. 120:482.

$\left({ }^{23}\right)$ Jones, D., An Index of Ancient Egyptian Titles I, p. 321:1183.

$\left({ }^{24}\right)$ Jones, D., An Index of Ancient Egyptian Titles II, p. 497:1862.

$\left({ }^{25}\right)$ Jones, D., An Index of Ancient Egyptian Titles II, p. 724:2637.

$\left({ }^{26}\right)$ Jones, D., An Index of Ancient Egyptian Titles II, p. 725:2642.

$\left({ }^{27}\right)$ Fischer preferred the reading of that title as sd3wty-bity, cf., Fischer, H., Egyptian Titles of the Middle Kingdom, pp. 77, 86.

$\left({ }^{28}\right)$ Jones, D., An Index of Ancient Egyptian Titles II, p. 763:2775.

$\left({ }^{29}\right)$ Jones, D., An Index of Ancient Egyptian Titles II, p. 892:3268.

$\left({ }^{30}\right)$ Jones, D., An Index of Ancient Egyptian Titles II, p. 932:3438.

$\left({ }^{31}\right)$ Jones, D., An Index of Ancient Egyptian Titles II, p. 941:3471.

$\left.{ }^{32}\right) \mathrm{Wb}$ I, p. 79 [10-23].

$\left({ }^{33}\right)$ Firth, C. and Gunn, B., Teti Pyramid Cemeteries I, pp. 105-106; Helck, W., Untersuchungen zu den Beamtentiteln, p. 118 n. 46.

$\left({ }^{34}\right)$ Jones, D., An Index of Ancient Egyptian Titles I, p. 10:39.

$\left({ }^{35}\right)$ Dreyer, G., "Umm el-Qaab: Nachuntersuchungen im Frühzeitlichen Königsfriedhof 5./6. Vorbericht”, p. 61.

$\left.{ }^{36}\right)$ Kaplony, P., Kleine Beiträge zu den Inschriften der Ägyptischen Frühzeit, pp. 43-44.

$\left({ }^{37}\right)$ Petrie, W. et al., Medum, pls. 17, 20, 23 ; Borchardt, L., Das Grabdenkmal des Königs Ne-User-Re, p. 71.

$\left({ }^{38}\right)$ Strudwick, N., The Administration of Egypt, p. 310 tb.30.

$\left.{ }^{39}\right)$ Altenmüller, H., Die Wanddarstellungen im Grab des Mehu in Saqqara, p. 37.

$\left({ }^{40}\right)$ Strudwick, N., The Administration of Egypt, p. 310 tb.30.

$\left({ }^{41}\right)$ Gardiner, A., Egyptian Grammar, p. 478 (M1).

$\left({ }^{42}\right)$ Gardiner, A., Egyptian Grammar, p. 478.

$\left({ }^{43}\right) \mathrm{Wb} \mathrm{I}$, p. 79.

$\left({ }^{44}\right)$ Gardiner, A., Egyptian Grammar, p. 454.

$\left({ }^{45}\right)$ Helck, W., Untersuchungen zu den Beamtentiteln, p. 36.

$\left({ }^{46}\right)$ Sethe, K., Die Altaegyptischen Pyramidentexte I, PT 807-808 sp. 437.

$\left({ }^{47}\right)$ Faulkner, R., The Ancient Egyptian Coffin Texts I, spells 1-354, pp. 142 (sp. 164), 148 (sp. 173), 177 (sp. 225).

$\left({ }^{48}\right)$ Strudwick, N., The Administration of Egypt, p. 310 tb.30.

$\left({ }^{49}\right)$ Y De Preter, D., "N.y-Ppy: A New vizier of the Sixth Dynasty?", pp. 261-268.

$\left({ }^{50}\right)$ James, T. and Apted, M., The Mastaba of Khentika called Ikhekhi, p. 9[19].

$\left({ }^{51}\right)$ Mariette, A., Abydos II, pl. 43b.

$\left({ }^{52}\right)$ Davies, N. de G., The Rock Tombs of Sheikh Saïd, pls. 29-30.

$\left({ }^{53}\right)$ Fischer, H., "A Stela of the Heracleopolitan Period at Saqqara: the Osiris 'Iti", ZÄS 90, 1963, p. 37.

$\left({ }^{54}\right) \mathrm{Wb}$ II, p. 256 [16].

$\left({ }^{55}\right)$ For names of wigs for men and women cf.,

سميرة أحمد مدني: الثعر المستعار في مصر القديمة حتى نهاية الدولة الحديثة، رسالة ماجستير غير منشورة، كلية الآداب، جامعة الأسكندرية، 2012، صاية صلية 1-25. 
$\left({ }^{56}\right)$ Pierret, P., Recueil d'inscriptions inédites du Musée Égyptien du Louvre I, pp. 1-4.

$\left({ }^{57}\right)$ Hassan, S., Giza IV, pp. 164, 182, figs. 115, 128 ; Jones, D., An Index of Ancient Egyptian Titles I, p. 323:1187, the expression $H r$ is a metaphor refered to the king whom the Iry $n f r-h 3 t$ served.

$\left({ }^{58}\right)$ Brovarski dated him by the early long reign of Pepy II, Brovarski, E., "Overseers of Upper Egypt in the Old to Middle Kingdoms", p. 28 (42).

$\left({ }^{59}\right)$ Blackman, A., The Rock Tombs of Meir IV, pls. 4, 4a. Who is dated by the early to middle reign of Pepy II, Brovarski, E., "Overseers of Upper Egypt in the Old to Middle Kingdoms", p. 24 (12).

$\left({ }^{60}\right)$ Fischer, H., The Tomb of I'p at El Saff, pp. 21 (2), 22.

$\left({ }^{61}\right)$ It was firstly held by $S n \underline{d} m-\hat{i} b /$ Mhi Unis's vizier, cf., Piacentini, P., Scribes I, p. 300; Borchardt, L., Denkmäler des Alten Reiches I, p. 121 (CG 1439); II, p. 55 (CG 1575).

$\left({ }^{62}\right)$ Wb II, p. 13 [22]; Nims, C., "Some notes on the family of Mereruka", p. 647 n. 45 .

$\left({ }^{63}\right)$ Kanawati, N., Akhmim in the Old Kingdom, pp. 117-119.

$\left({ }^{64}\right)$ Firth, C. and Gunn, B., Teti Pyramid Cemeteries I, p. 109 n.3; James, T. and Apted, M., The Mastaba of Khentika called Ikhekhi, pp. 12-13; Fischer, H., Dendera in the third Millennium B.C., p. 97 n. 442.

$\left({ }^{65}\right) \mathrm{Wb}$ III, p. 326.

$\left({ }^{66}\right)$ FCD, p. 139.

$\left({ }^{67}\right)$ Gardiner, A., "The Mansion of life and the Master of the king's largess", p. 85; he also referred that the dualism in that title didnot indicate Upper and Lower Egypt, Gardiner, A., "The Mansion of life and the Master of the king's largess", p. 85.

$\left({ }^{68}\right)$ Gardiner, A., "The Mansion of life and the Master of the king's largess", p. 85; Helck, W., Untersuchungen zu den Beatentiteln, p. 33; Helck, W., "Palastverwaltung", pp. 647-651.

$\left({ }^{69}\right)$ Helck, W., Untersuchungen zu den Beamtentiteln, p. 33.

$\left({ }^{70}\right)$ It was probably first held by $D w 3-n-R^{C}$, cf., Strudwick, N., The Administration of Egypt, p. 162 (161).

$\left({ }^{71}\right)$ It was found in El-Hawawish, Kanawati, N., The rock tombs of El-Hawawish III, p. 8 (26), fig. 8, pl.1.

$\left.{ }^{72}\right)$ Junker, H., Giza II, p. 162.

$\left({ }^{73}\right)$ Gardiner, A., "The Mansion of life and the Master of the king's largess", p. 85.

$\left({ }^{74}\right)$ Gardiner, A., "The Mansion of life and the Master of the king's largess", p. 85 n.3.

$\left({ }^{75}\right)$ It was held for the first time in the first dynasty by Hemaka, Emery, W., Archaic Egypt, p. 75.

$\left.{ }^{76}\right)$ Strudwick, N., The Administration of Egypt, p. 310. 
$\left({ }^{77}\right)$ It is attested in Sheikh Said, cf., Davies, N. de G., The Rock Tombs of Sheikh Saïd, pp. 24, 27, 30 and in Deir el Gebrawi, cf., Davies, N. de G., Rock Tombs of Deir el Gebrâwi I, p. 9; II, pp. 1-2.

$\left({ }^{78}\right)$ Uphill, E., "The office $s d 3 w t y$ bity", p. 250, Murray in her Index confirmed that the holders of h3ty-` were also htmty-bity, Murray, M., Index of Names and Titles of the Old Kingdom, pp. 59-61.

$\left(^{79}\right)$ Uphill, E., "The Office of $s \underline{d} 3$ wty bity", p. 250.

$\left({ }^{80}\right)$ Strudwick, N., The Administration of Egypt, p. 117 (96), he was the son of the vizier $N f r-M 3^{`} t$ of Medum, cf., Kanawati, N., The Egyptian Administration in the Old Kingdom, p. 10.

$\left({ }^{81}\right)$ Strudwick, N., The Administration of Egypt, p. 310 tb. 30.

$\left({ }^{82}\right)$ Strudwick, N., The Administration of Egypt, p. 175.

$\left({ }^{83}\right)$ Fischer, H., The Tomb of 'T' $p$ at El Saff, p. 21.

$\left({ }^{84}\right)$ Eyre, C., "Weni's career and Old Kingdom Historiography", p. 110.

$\left({ }^{85}\right)$ Kaplony, P., "Totenpriester", pp. 679-680; Jones, D., An Index of Ancient Egyptian Titles I, pp. 189-190: 711-712; II, p. 755:2751.

$\left({ }^{86}\right)$ Roth, A., Egyptian Phyles in the Old Kingdom, pp. 91-92; Muhs, B., The Ancient Egyptian economy 3000-30 BCE, p. 43.

$\left({ }^{87}\right)$ Muhs, B., The Ancient Egyptian economy 3000-30 BCE, p. 43.

$\left({ }^{88}\right)$ Perhaps the Phyle system which allowed shift alternation helped to be appointed in more than one temple, Roth, A., Egyptian Phyles in the Old Kingdom, pp. 91-92; Muhs, B., The Ancient Egyptian economy 3000-30 BCE, p. 43.

$\left({ }^{89}\right)$ In the middle kingdom, it was linked with gods' temples and the mortuary temples of the pyramids, cf., Ward, W., Index of Ancient Egyptian Titles, p. 154:1327-1330.

$\left({ }^{90}\right)$ Russmann, E., “A second Style in Egyptian Art of the Old Kingdom”, pp. 269279.

$\left({ }^{91}\right)$ Brovarski, E., "A second style in Egyptian Relief of the Old Kingdom", pp. 54-56, 83-84.

$\left({ }^{92}\right)$ Fischer, H., The Orientation of Hieroglyphs, pp. 48-50, figs. 49-51.

$\left({ }^{93}\right)$ Fischer, H., "Some early monuments from Busiris in the Egyptian Delta", p. 22.

$\left({ }^{94}\right)$ Brovarski, E., "False Doors and History: the sixth Dynasty", p. 100.

$\left({ }^{95}\right)$ Which is composed of $h 3 t h 3$ hnkt h3 $k 3 w$ h3 $3 p d w$; that role was carried out before by the lector priests but by the end of Pepy I's reign it run out and left for the passers to recite it, Sainte Fare Garnot, J., L'appel aux vivants dans les textes funéraires, p. 93.

$\left({ }^{96}\right)$ Sainte Fare Garnot, J., L'appel aux vivants dans les textes funéraires, pp. 1920.

$\left({ }^{97}\right)$ PM III ${ }^{2} / 2$, pp. 427, 686.

$\left({ }^{98}\right)$ Baer, K., Rank and Title in the Old Kingdom, p. 241 [225]. 


\section{Bibliography:}

- Altenmüller, H., Die wanddarstellungen im Grab des Mehu in Saqqara, Mainz am Rhein, 1998.

- Baer, K., Rank and Title in the Old Kingdom: The Structure of the Egyptian Administration in the Fifth and Sixth Dynasties, Chicago, 1960.

- Blackman, A., The Rock Tombs of Meir, vol. IV, London, 1924.

- Borchardt, L., Das Grabdenkmal des Königs Ne-User-Re, Leipzig, 1907.

- Borchardt, L., Denkmäler des Alten Reiches, im Museum von Kairo, 2 volumes, Berlin.

- Brovarski, E., "False Doors and History: The Sixth Dynasty", in: Barta, M. (ed.), The Old Kingdom Art and Archaeology, Prague, 2006.

- Brovarski, E., "A Second Style in Egyptian Relief of the Old Kingdom", in: Thompson, S. and Der Manuelian, P. (eds.), Egypt and Beyond, essays presented to Leonard H. Lesko, Brown, 2008.

- Brovarski, E., "Overseers of Upper Egypt in the Old to Middle Kingdoms", ZÄS 141, part 2, 2014.

- Brunner-Traut, E., “Gesten”, LÄ II, 1977.

- Davies, N. de G., The Rock Tombs of Sheikh Saïd, London, 1901.

- Davies, N. de G., Rock Tombs of Deir el Gebrâwi, 2 volumes, London, 1902.

- Dreyer, G., "Umm el-Qaab: Nachuntersuchungen im Frühzeitlichen Konigsfriedhof 5./6. Vorbericht", MDAIK 49, 1993.

- El-Khadragy, M., "Two Old Kingdom False doors from Saqqara", GM 174, 2000.

- Emery, W., Archaic Egypt, Baltimore, 1961.

- Eyre, C., "Weni's career and Old Kingdom Historiography", in: Eyre, C., Leahy, A. and Leahy, L. (eds.), The Unbroken Reed, Studies in the Culture and Heritage of Ancient Egypt in Honour of A.F. Shore, London, 1994.

- Faulkner, R., A Concise Dictionary of Middle Egyptian, Oxford, 1968.

- Faulkner, R., The Ancient Egyptian Coffin Texts, volume I, spells 1-354, warminster, 1973. 
Firth, C. and Gunn, B., Excavations at Saqqara: Teti Pyramid Cemeteries, vol. I, Cairo, 1926.

- Fischer, H., "A stela of the Heracleopolitan period at Saqqara: the Osiris Iti”, ZÄS 90, 1963.

- Fischer, H., Dendera in the Third Millennium B.C. down to the Theban domination of Upper Egypt, New York, 1968.

- Fischer, H., "Some Early Monuments from Busiris in the Egyptian Delta", MMJ 11, 1976.

- Fischer, H., The Orientation of Hieroglyphs: Reversals, New York, 1977.

- Fischer, H., The Tomb of I'p at El Saff, New York, 1996.

- Fischer, H., Egyptian Titles of the Middle Kingdom, A Supplement to Wm. Ward's Index, second edition, New York, 1997.

- Gardiner, A., "The Mansion of Life and the Master of the King's Largess", JEA 24, 1938.

- Gardiner, A., Egyptian Grammar, third edition, Oxford, 1986.

- Green, L., "Hairstyles", in: Redford, D. (ed.), OEAE, vol. II, Oxford, 2001.

- Hassan, S., Excavations at Giza, volume IV, Cairo, 1943.

- Helck, W., Untersuchungen zu den Beamtentiteln des Ägyptischen Alten Reiches, Glückstadt, 1954.

- Helck, W., "Palastverwaltung", in: LÄ IV, 1982.

- James, T. and Apted, M., The Mastaba of Khentika called Ikhekhi, London, 1953.

- Jones, D., An Index of Ancient Egyptian Titles, Epithets and Phrases of the Old Kingdom, 2 vols., Oxford, 2000.

- Junker, H., Giza: Bericht über die von der Akademie der wissenschaften in wien auf gemeinsame kosten mit Dr. Wilhelm Pelizäus unternommenen Grabungen auf dem Friedhof des Alten Reich bei den pyramiden von Giza: vol. II, wien, 1934.

- Kanawati, N., The Egyptian Administration in the Old Kingdom, Warminster, 1977.

- Kanawati, N., The rock tombs of El-Hawawish: The Cemetery of Akhmim, volume III, Sydney, 1982.

- Kanawati, N., Akhmim in the Old Kingdom, Sydney, 1992.

- Kaplony, P., Kleine Beiträge zu den Inschriften der Ägyptischen Frühzeit, ÄA 15, Wiesbaden, 1966. 
- Kaplony, P., “Totenpriester”, LÄ VI, 1986.

- Kuraszkiewicz, K., "Two fragments of False-door frame of NyPepy from West Saqqara", ET 19, 2001.

- Mariette, A., Catalogue Général des Monuments D’Abydos, Paris, 1880.

- Mariette, A., Les Mastabas de l'Ancien Empire, Maspero, G. (ed.), Paris, 1884.

- Muhs, B., The Ancient Egyptian economy, 3000-30 BCE, Cambridge, 2016.

- Murray, M., Index of Names and Titles of the Old Kingdom, BSAES 1, London, 1908.

- Nims, Ch., "Some Notes on the Family of Mereruka", JAOS 58, 1938.

- Petrie, W. et al., Medum, London, 1892.

- Piacentini, P., Les scribes dans la société égyptienne de l'Ancien Empire, volume I, Paris, 2002.

- Pierret, P., Recueil d'inscriptions inédites du Musée Egyptien du Louvre, volume I, Paris, 1874.

- Ranke, H., Die Ägyptischen Personennamen, vol. I, Glückstadt, 1935.

- Roth, A., Egyptian Phyles in the Old Kingdom: The evolution of a system of Social Organization, Chicago, 1991.

- Russmann, E., "A Second Style in Egyptian Art of the Old Kingdom”, MDAIK 51, 1995.

- Sainte Fare Garnot, J., L'appel aux vivants dans les textes funéraires égyptiens des origines à la fin de l'Ancien Empire, Caire, 1938.

- Sethe, K., Die Altaegyptischen Pyramidentexte, vol. I, Leipzig, 1906.

- Sethe, K., Urkunden des Alten Reiches, vol. I, Leipzig., 1933.

- Strudwick, N., The Administration of Egypt in The Old Kingdom: the Highest Titles and their Holders, London, 1985.

- Uphill, E., "The Office $s \underline{d} 3$ wty bity", JEA 61, 1975.

- Ward, W., Index of Egyptian Administrative and Religious Titles of the Middle Kingdom, Beirut, 1982.

- Y De preter, D., "N.y-PPy: A New Vizier of the Sixth Dynasty?", SAK 31, 2003. 